\title{
A Case of Lambert-Eaton Myasthenic Syndrome Presenting with Dry Mouth
}

\author{
Yoshifumi Fujita, Kazumasa Suzuki, Yoshiaki Mori, \\ Ai Suzuki and Takashi Hatano
}

Lambert-Eaton myasthenic syndrome (LEMS) is an immunological disease known to be associated with malignant disease, and is characterized by muscle weakness and autonomic neuropathy. Small cell lung cancer is one of the most important causes of this condition. We encountered a case of LEMS associated with small cell lung cancer presenting with dry mouth.

A 65-year-old man visited to our hospital with the complaints of dry mouth, muscle weakness of the lower limbs and gait disturbance. The patient showed significant hyposalivation, but the diagnosis of Sjogren's syndrome could not be established based on the results of minor salivary gland biopsy and blood tests. Chest CT showed a nodular lesion in the left lung and swollen lymph nodes in the mediastinum. In regard to the neurological findings, the patient showed hyporeflexia, and lower limb weakness. Therefore, we suspected the possibility of LEMS associated with lung cancer. Video-assisted thoracic surgery was performed, and small cell lung cancer was diagnosed based on histopathological examination of the resected specimen. Five courses of chemotherapy (cisplatin+etoposide) and concurrent radiotherapy at a total dose of $45 \mathrm{~Gy}$ were administered, which resulted in a complete response.

Autonomic neuropathy such as that associated with LEMS should be borne in mind in the differential diagnosis of dry mouth.

Keywords : Lambert-Eaton myasthenic syndrome, dry mouth, small cell lung cancer

\section{References}

1) Screebny LM : 口腔乾燥症の診断, 治療と臨床症状. 唾 液 歯と口腔の健康（河野正司監訳）。47-73 頁, 医歯薬出 版，東京，1997。

2) 高橋 哲, 友寄泰樹 : 口腔乾燥症の臨床一診断と治療のガ イドライン 全身状態と唾液分泌低下. 歯界展望 103：5356, 2004

3) Anderson HJ, Churchill-Davidson HC and Richardson AT : Bronchial neoplasm with myasthenia; prolonged apnoea after administration of succinylcholine. Lancet 265: 1291-1293, 1953.

4) Lambert EH, Eaton LM and Rooke ED : Defect of neuromuscular conduction associated with malignant neoplasms. Am J Physiol 187: 612-613, 1956.

5) Eaton LM and Lambert EH : Electromyography and electric stimulation of nerves in disease of motor unit; observations on myasthenic syndrome associated with malignant tumors. J Am
Med Assoc 163: 1117-1124, 1957.

6) Graus F, Delattre JY, Antoine JC, et al. : Recommended diagnostic criteria for paraneoplastic neurological syndromes. J Neurol Neurosurg Psychiatry 75: 1135-1140, 2004.

7) Vedeler CA, Antoine JC, Giometto B, et al. : Management of paraneoplastic neurological syndromes: report of an EFNS Task Force. Eur J Neurol 13: 682-690, 2006.

8）本村政勝, 白石裕一: Lambert-Eaton 筋無力症候群. 医のあ ゆみ 201: 189-192, 2002.

9）佐橋 功：Lambert-Eaton 症候群の病態 - 治療. 神経治療 9: 349-354, 1992.

10）本村政勝: Lambert-Eaton 筋無力症候群一本邦 110 症例の検 討. 臨神経 39: 1237-1239, 1999.

11）田中惠子：Lambert-Eaton 筋無力症候群. Brain Med 18: 140-144, 2006.

12) Maddison P, Newsom-Davis J, Mills KR, et al. : Favourable prognosis in Lambert-Eaton myasthenic syndrome and smallcell lung carcinoma. Lancet 353: 117-118, 1999. 


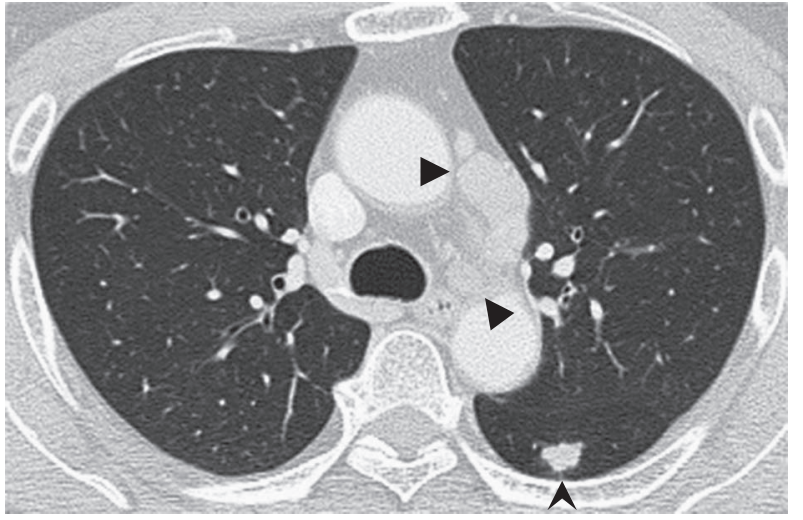

Chest CT

A nodular lesion in the left lung $(>)$ and swollen lymph nodes are seen in the mediastinum $(\triangleright)$.

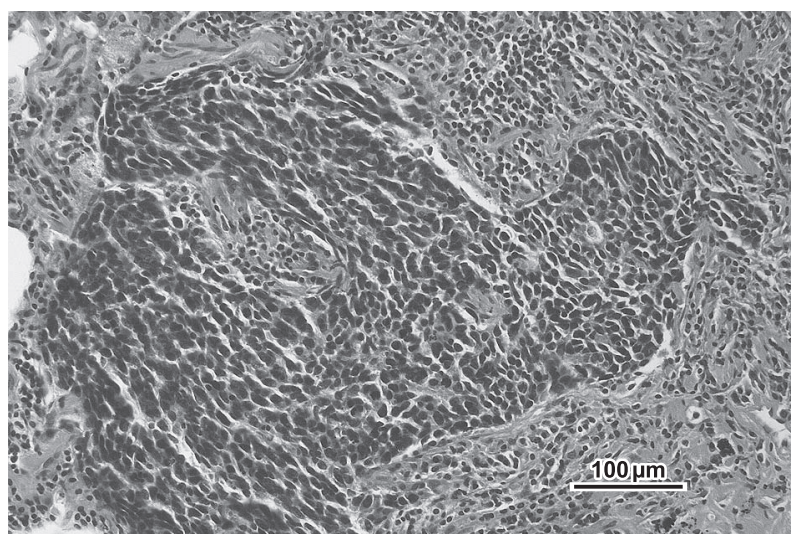

Pathological findings (H\&E staining) 